\title{
COVID 19 and Online Learning in Post Graduate Management Programme: An Empirical Analysis of Students' Perception
}

\author{
Sushma Verma \\ Vivekanand Education Society's Institute of Management Studies and Research, Mumbai \\ Tushar Ranjan Panigrahi \\ Unitedworld School of Business, Karnavati University, Gandhinagar \\ Divya Alok \\ SASMIRA's Institute of Management Studies and Research, Mumbai
}

\begin{abstract}
In University regulated Tier II B Schools in India, the prominent mode of instruction has been traditional face to face, teaching. The extent of technology to be incorporated in educational pedagogy was always debated. However, with the sudden COVID-19 pandemic, all institutions were compelled to adopt online teaching methodologies. With this background, this paper attempts to analyze the perception of students of Post Graduate Management Programmes from the four different Universities in state of Maharashtra, India, about their online learning experience during the pandemic. The study also attempts to identify various factors that have a bearing on student's perceptions regarding the effectiveness of online teaching. For the purpose of quantitative analysis, factor analysis and multiple regression have been used. Based on the results of quantitative analysis, appropriate qualitative conclusions have been derived. The results of the study in terms of perception of students regarding online learning can contribute significantly in developing a blended approach for management education as per the latest UGC guidelines (2020).
\end{abstract}

Keywords: management education, factor analysis, online learning, students' perception

\section{INTRODUCTION}

In University regulated tier II-B Schools in India, the prominent mode of instruction has always been conventional face to face teaching. The extent to which the latest developments in the field of Information Technology (IT) may be incorporated in educational pedagogy continues to be a matter of discussion and deliberation. However, with the onset of COVID-19, maintaining social distancing has become mandatory. Thus, online teaching is the only solution for Universities in the prevailing situation. This process of abrupt change is challenging both for students' and educators. As per Lewin et al. (2009), it is altogether a different experience to teach online as compared to traditional face to face direct teaching requiring different skill sets. Better understanding of students' experiences and their expectations can lead to a better usage of online learning as an educational tool. As per Sahin and Shelly (2008), students' perceptions should be given paramount importance in design and delivery of any online course since it significantly influences learning 
outcome (Zhang and Bhattacharyya, 2008). Hence, several researchers have highlighted the significance of studying students' perspectives towards online learning (Cunningham et al.2009; Rhema and Miliszewska,2014).

The purpose of this study is to understand the perceptions and experiences of students' when they were shifted suddenly and compulsorily to online classes in view of the pandemic. In this background, the following objectives have been set:

- To know the students' perception regarding various online teaching options.

- To examine the perceived effectiveness of online teaching.

- To identify various factors that have a bearing on students' perceptions regarding effectiveness of online teaching.

- To know the students' overall experience of online learning.

This study provides a comprehensive picture of management students' dealing with online learning environment and can help in developing learner centered tools for better teaching learning experience of students. Results from this study can aid in development of rich blended approach in University post graduate management programmes. This becomes more relevant considering the latest University Grants Commission (UGC) guidelines (2020) which have recommended a methodology comprising of 75 per cent traditional (classroom) and 25 per cent online learning.

This paper is organized as follows: Section 2 discusses the literature related to the subject matter, in section 3, research methodology has been stated in detail followed by results and discussion in section 4 , concluding observations in section 5 and limitations and future scope in section 6 .

\section{LITERATURE REVIEW}

Teaching at University level requires a set of complex skills and practices. Though there is no single definition as to what can be called as an effective teaching (Trigwell, 2011), broadly any teaching which is student centric and focuses on students' learning can be considered to be effective.

From the year 1990, significant increase has been observed in online learning and Higher Education Institutions (HEIs) have started investing significantly in technologies to facilitate online learning (Deng and Tavares, 2013). These technologies facilitate online learning by aiding students' collaboration and also by tracking their progress (Islam, 2012).

In the initial phases of conception and implementation of online teaching, educators were skeptical about the ability of online classes to match traditional class room teaching in terms of effectiveness. Empirical evidences for this are mixed. There are ample of researches concluding that online teaching can be as effective as face-to-face traditional class room teaching (Demuyakor,2020; Denny, 2013; Feeley and Parris, 2012; Lack, 2013; Nguyen, 2015). As per Wang and Hu (2019), online learning can be considered to be a better alternative for students. There are studies indicating increasing acceptance of online teaching and learning amongst students' (Nguyen, 2015; Waits, 2003). However, Dunbar and Sutcliffe (2013), concluded that class room teaching is superior as compared to online teaching since it is a known fact that more learning occurs in a social setup as compared to an a-social setup. Tratnik et al. (2019), observed that the level of satisfaction of learners was more in traditional face to face learning as compared to online learning.

There are various studies that attempted to explore perceptions of students regarding this form of online teaching and also during the prevailing pandemic situation. Agarwal and Kaushik (2020), studied the post graduate medical students' perceptions of online learning during COVID-19 and concluded that the responses of students were positive. Whereas Verma et.al (2020), tried to explore the perception of undergraduate medical students about online teaching during prevailing pandemic and concluded that students were quite satisfied with online teaching. Linjawi and Alfadda (2018), assessed students' perception, and attitude towards online teaching in case of dental education in Saudi Arabia and stated that various factors should be considered for implementing online teaching-learning such as proficiency in English, various economic, organizational issues and also technological issues. Bauk, Kopp et al. (2013), 
conducted a study to know the perceptions about significance of various e-learning features involving students, instructors and IT (Information Technology) cell. Azliza et al. (2012), conducted a multiple regression analysis for assessment of Malaysian students' perception about e-learning programme

Existing Literature identifies several factors having a bearing on students' perceptions about effectiveness of online teaching. It is a well known fact that online teaching is technology based (DonitsaSchmidt and Topaz, 2018; Garcia and Badia, 2017). As per Keller and Cernerud (2002), variables such as students' age, gender, learning styles, past experiences have a bearing on acceptance of technology in learning. As per Technology Acceptance Model (TAM) Proposed by Davis et al. (1989), perceived usefulness and perceived ease of use are among the major factors having a bearing on acceptance of computer technology.

There are several studies identifying communication as one of the most significant elements having a bearing on the success of online teaching (Arbaugh and Benbunan-Fich, 2007; Gregory, 2003; Wilkes et al., 2006). Harris and Kelley (2004-2006) identified that four channels of communication i.e., a.) student to content b.) student to instructor c.) Student to student and d.) student to community is extremely important for success of any online course. As per Cooper (2000), communication between students and course instructor is very significant. There are researches clearly highlighting the importance of peer-to-peer interaction in enriching the students online learning experience and significantly influencing the students' perception about online teaching (Driver, 2002; McGreal and Elliott, 2004; Swan, 2001).

Existing researches (Howland \& Moore, 2002; Shea et al.,2001; Vonderwell, 2003; Woods ;2002) have also highlighted the significance of instructor's feedback in framing the perception of students about online teaching. High correlation has been observed between a prompt instructors' feedback and student's satisfaction with online courses (Shea et al, 2001). In an e-learning assessment model proposed by Ozkan and Koseler (2009), attitude of instructor is considered to be one of the important dimensions affecting learner's perception and satisfaction. Tung and Chang (2008), on the basis of their study stated that perceived usefulness, technical compatibility and the perceived ease of use of this technology influences the student's perceptions about online learning. As per Jia et al. (2009), perceived ease of use significantly influences intention of the user to adapt to technology.

Regular support in the form of technical assistance and student support services is also considered to be a very important element for online learning (Choy et al.,2002). Annamdevula and Bellamkonda (2016), stated that universities should make proper resource allocation for various support services for providing improved educational facilities.

There are studies highlighting the limitations of E-learning and concluded that a standalone E-learning module may not be effective as students are devoid of class room interaction with Professors or fellow students (Laine, 2003; Wiles et al.,2006). Artino (2008), stated that online learning may be challenging for students who lack confidence, self-motivation etc.

Kose (2010), explained in detail about the development of E-learning opportunities for blended learning using Web 2.0 tools. Perez-Marin et al. (2012), proposed a model for blended learning for Spain that generated positive outcome. Kashefi et al. (2012) also stated that blended environment is more conducive for teaching learning process. According to Dogbey et al. (2017), online teaching can aid and support meaningful interaction between instructors, students and resources.

Though there are various studies that conclude that online teaching can be as effective as traditional class room teaching however, the situation in case of a sudden transition from the usual and well established, direct traditional offline teaching to an online teaching module, may be different. A shift towards online teaching requires detailed planning and also investments in various areas (Bao,2020; Filius et al.,2019). This leads to the first research question of understanding the student's perception about the experience and acceptance of this mode of teaching especially when they had to shift abruptly to online mode of learning in view of the prevailing pandemic. Here students' views, regarding various modes of online teaching and effectiveness of online teaching were also considered. In addition, study also attempts to understand the students' views about major challenges faced by them in online teaching learning process. Study also attempts to identify the important factors having a bearing on students' perception. 


\section{RESEARCH METHODOLOGY}

This is a semi exploratory study attempting to analyze the perceptions of students of Post Graduate Management Programmes from four different universities in the state of Maharashtra, India regarding their online teaching and learning experience while transiting to online mode due to COVID 19. A Total of 800 Questionnaires were prepared and administered online against which a total of 564 responses were received. Special attempt was made to ensure that questionnaire was administered only to second year students of the full-time course of two years by contacting with the coordinators and getting email ids. Questionnaire had three sections. First section includes basic demographic information, second section attempts to understand the students' perceptions regarding various online teaching options and the perceived effectiveness of online teaching and third section consists of questions about students' perception regarding major challenges in online teaching learning. Total twenty-five questions were included to collect the required data. Five-point Likert scale has been used to understand the student's perception ranging from strongly disagree (1) to strongly agree (5). Cronbach's Alpha (1951) was used for testing the reliability of the scale for internal consistency. The value of Cronbach's alpha for the entire instruments is 0.785 which is more than 0.70 and value above 0.70 is considered as good (Schmitt,1996). So, it can be said that scales are reliable showing internal consistency of the acceptable level. The responses from the questionnaire have been analyzed using Software Statistical Package for the Social Sciences (SPSS). Descriptive statistics were used for summarizing student responses. Factor Analysis has been used for identifying the most important factors and thereafter multiple regression has been performed. Variables for methods adopted for online teaching, have been identified on the basis of detailed discussions, with the faculty members from different universities, included in the study. Discussion with the faculties revealed that following are the common methods adopted for online teaching-

- Online learning with sharing of notes by faculties

- Sharing of prepared power point presentation (PPTs) by faculties

- Sharing of uploaded you tube lectures

- Organizing Webinars

- Online interactive teaching using combination of methods

Different parameters affecting student satisfaction and their perception about effectiveness of online teaching-learning have been identified by reviewing the existing literature extensively. Following parameters are considered for assessing the effectiveness of online teaching:

- Instructors enthusiasm

- Instructors ability to influence, motivate and inspire students

- Ease of learning in terms of conceptual understanding

- Sufficient learner support

- Explanatory feedback from the Instructor

- Opportunities for students to interact with each other

- Opportunities for students to interact with the instructor

- Students' technical compatibility

Table 1 shows the parameters considered for assessing the effectiveness of online teaching along with some of the literature using these variables. 
TABLE 1

SUMMARY OF PARAMETERS

\begin{tabular}{|l|l|}
\hline Parameter chosen & \multicolumn{1}{|c|}{ Existing literature using these parameters } \\
\hline Instructors enthusiasm & Ozkan and Koseler (2009), Hativa et al. (2001) \\
\hline $\begin{array}{l}\text { Instructors ability to influence, } \\
\text { motivate and inspire students }\end{array}$ & Hativa et al. (2001), Vonderwell, 2003 \\
\hline Ease of learning & Davis et al. (1989), Tung and Chang (2008), Jia et al. (2009) \\
\hline Learner support & Annamdevula and Bellamkonda (2016), Choy et al.,2002 \\
\hline $\begin{array}{l}\text { Explanatory feedback from the } \\
\text { Instructor }\end{array}$ & $\begin{array}{l}\text { Howland and Moore, 2002; Shea et al.,2001; Vonderwell, } \\
\text { 2003; Woods ;2002 }\end{array}$ \\
\hline $\begin{array}{l}\text { Opportunities for students to interact } \\
\text { with each other }\end{array}$ & $\begin{array}{l}\text { Driver, 2002; McGreal and Elliott, 2004; Swan, 2001; Harris } \\
\text { and Kelley (2004-2006), Dogbey et al. (2017) }\end{array}$ \\
\hline $\begin{array}{l}\text { Opportunities for students to interact } \\
\text { with the instructor }\end{array}$ & $\begin{array}{l}\text { Harris and Kelley (2004-2006), Laine, 2003, Dogbey et al. } \\
\text { (2017), }\end{array}$ \\
\hline Students' technical compatibility & Bauk, Kopp et al. (2013), Dogbey et al. (2017), \\
\hline
\end{tabular}

Source: Authors' compilation

\section{DATA ANALYSIS}

Against a total of 800 questionnaires that was administered, a total 564 responses were received, which makes it approximately 70.50 per cent. Creswell and Poth (2016) and Babchuk (2017) have stated that any study having response rate greater than 50 per cent can by analyzed appropriately.

TABLE 2

DEMOGRAPHIC PROFILE OF PARTICIPANTS $(\mathrm{N}=564)$

\begin{tabular}{|l|l|c|c|c|}
\hline Variable & Category & Frequency & Percent & Valid percent \\
\hline Gender & Female & 304 & 53.9 & 54 \\
& Male & 260 & 46.1 & 46 \\
& Total & 564 & 100 & 100 \\
\hline Online Course & Experienced & 214 & 37.95 & 38 \\
Experience & Not Experienced & 350 & 62.05 & 62 \\
& Total & 564 & 100 & 100 \\
\hline
\end{tabular}

Source: Authors' Calculation

As it can be seen from the Table 2 that approximately 54 per cent of the respondents are female and 46 per cent are male students. Approximately 38 per cent of the respondents have some experience of online course and 62 per cent of students surveyed have no experience of online learning. 
TABLE 3

STUDENTS PERCEPTIONS REGARDING METHOD WORKING BEST IN ONLINE LEARNING ENVIRONMENT

\begin{tabular}{|l|l|l|}
\hline Parameters & Mean & $\begin{array}{l}\text { Standard Deviation } \\
\text { (SD) }\end{array}$ \\
\hline Online learning with sharing of notes & 3.75 & 1.05 \\
\hline Sharing of prepared PPTs & 3.90 & 1.02 \\
\hline Sharing of uploaded YouTube lectures & 3.65 & 1.02 \\
\hline Organizing Webinars & 3.05 & 1.05 \\
\hline Online interactive teaching using combination of various methods. & 3.60 & 1.03 \\
\hline
\end{tabular}

Source: Authors' Calculation

As it can be seen from table 3, sharing of prepared PPT will work best in an online environment and organizing webinars will work least. This may be due to the fact that the content of PPTs prepared by faculty members' is syllabus oriented and relatively simpler for students to comprehend.

TABLE 4

STUDENTS PERCEPTION ABOUT EFFECTIVENESS OF ONLINE TEACHING ON CHOSEN PARAMETERS

\begin{tabular}{|l|l|c|}
\hline Parameters & Mean & Standard Deviation (SD) \\
\hline Instructors Enthusiasm & 3.20 & 0.95 \\
\hline Instructors ability to influence, motivate and inspire students & 3.00 & 1.00 \\
\hline Ease of learning in terms of conceptual understanding & 2.85 & 0.90 \\
\hline Sufficient learner support & 3.03 & 1.02 \\
\hline Explanatory feedback from Instructor & 3.15 & 1.02 \\
\hline Opportunities for students to interact with each other & 3.00 & 1.05 \\
\hline Opportunities for students to interact with the instructor & 3.02 & 1.02 \\
\hline Students' technical compatibility & 3.00 & 1.06 \\
\hline
\end{tabular}

Source: Authors' Calculation

What is visible from the table 4 is that students are viewing online learning favorably. Perceived ease of learning, in terms of conceptual clarity, is an area of concern as seen from the table 4 . It also has the lowest standard deviation, indicating similar views of the participants. Instructors' enthusiasm is rated highest by the students as compared to all other factors. It indicates efforts taken by the instructors.

\section{TABLE 5 \\ STUDENTS PERCEPTION ABOUT MAJOR CHALLENGES IN ONLINE TEACHING AND LEARNING}

\begin{tabular}{|l|l|l|}
\hline Parameters & Mean & Standard Deviation (SD) \\
\hline Faculty to student communication and vice versa & 2.20 & 0.95 \\
\hline Student to Student Communication & 2.40 & 0.90 \\
\hline Technical Support & 2.85 & 0.90 \\
\hline Lack of readiness in faculty & 2.03 & 1.05 \\
\hline $\begin{array}{l}\text { Lack of awareness of students with learning style in case of } \\
\text { online teaching }\end{array}$ & 2.45 & 0.85 \\
\hline
\end{tabular}

Source: Authors' Calculation 
Table 5 clearly indicates that students perceive technical support as the biggest challenge in the online teaching environment followed by lack of awareness amongst them with the changed learning style.

Approximately 64 per cent students were satisfied with the online teaching learning activity of management institutes during the prevailing situation of pandemic. Approximately 57 per cent students agreed to the idea of having online classes to be a part of their teaching pedagogy in the post pandemic situation also.

\section{Factor Analysis}

Factor Analysis is used for identifying most important factor having a bearing on students' perception. Table 6 shows case processing summary depicting the valid cases. All 564 cases are included in factor analysis.

TABLE 6

CASE PROCESSING SUMMARY

\begin{tabular}{|ll|l|l|}
\hline & & $\mathrm{N}$ & $\%$ \\
\hline \multirow{4}{*}{ Cases } & Valid $^{*}$ & 564 & 100.0 \\
& Excluded $^{\mathrm{a}}$ & 0 & .0 \\
& Total & 564 & 100.0 \\
\hline
\end{tabular}

Listwise deletion based on all variables in the procedure.

Source: Authors' Calculation

\section{KMO and Bartlett's Test of Sphericity}

The Kaiser-Meyer Olkin (KMO) and Bartlett's Test are measure of sampling adequacy and correlation matrix. They are used for examining the appropriateness of Factor Analysis.

KMO value ranges from 0 to 1 . Value of .5 denotes the minimum acceptance level (Kaiser,1974). The Bartlett's test does comparison of the observed correlation matrix to the identity matrix. It is testing the null hypotheses that correlation matrix is an identity matrix considering the $95 \%$ level of significance, $\alpha=0.05$. This hypothesis needs to be rejected. Table 6 is showing a KMO value of 0.720 which is more than the accepted value of 0.5 and Barlett's test of Sphericity is significant with the p-value (Sig.) of $.000<0.05$. This satisfies the assumptions of factor analysis indicating the suitability of data for the same.

TABLE 7

KMO AND BARTLETT'S TEST

\begin{tabular}{|l|l|l|}
\hline \multicolumn{2}{|l|}{ Kaiser-Meyer-Olkin Measure of Sampling Adequacy. } & .720 \\
\hline \multirow{3}{*}{$\begin{array}{l}\text { Bartlett's Test } \\
\text { of Sphericity }\end{array}$} & Approx. Chi-Square & 5791.379 \\
\cline { 2 - 3 } & $\mathrm{df}$ & 28 \\
\cline { 2 - 3 } & Sig. & .000 \\
\hline
\end{tabular}

Source: Authors' Calculation

\section{Factor Extraction}

In factor analysis, principal component analysis (PCA) is used to reduce the number of variables in the data set. PCA attempts to explain the maximum amount of variance with the fewest number of principal components. After identifying this meaningful set of the variables, the next task is to group these variables under the particular factor and tag them in order to allocate some connotation to the factor loadings. Variables with higher loadings are considered to be as more significant and have greater influence on the tag chosen to signify the factor. 
Factor Extraction for Parameters considered for Online Teaching

Table 8 depicts the sum of factor loading for each variable. Only variables with value more than .5 can be considered for further analysis (Hair et al., 1995).

TABLE 8

COMMUNALITIES

\begin{tabular}{|l|l|l|}
\hline & Initial & Extraction \\
\hline Ease of learning in terms of conceptual understanding & 1.000 & .968 \\
Opportunities for students to interact with each other & 1.000 & .964 \\
Instructors enthusiasm & 1.000 & .913 \\
Sufficient learner support & 1.000 & .958 \\
Explanatory feedback from the instructor & 1.000 & .958 \\
Instructors ability to influence, motivate and inspire students & 1.000 & .990 \\
Opportunities for students to interact with the instructor & 1.000 & .966 \\
Students' technical compatibility & 1.000 & .911 \\
\hline
\end{tabular}

Extraction Method: Principal Component Analysis.

Source: Authors' Calculation

Factor Extraction for Parameters considered for Online Teaching

Journal of Applied Business and Economics Vol. 23(2) 2021115 


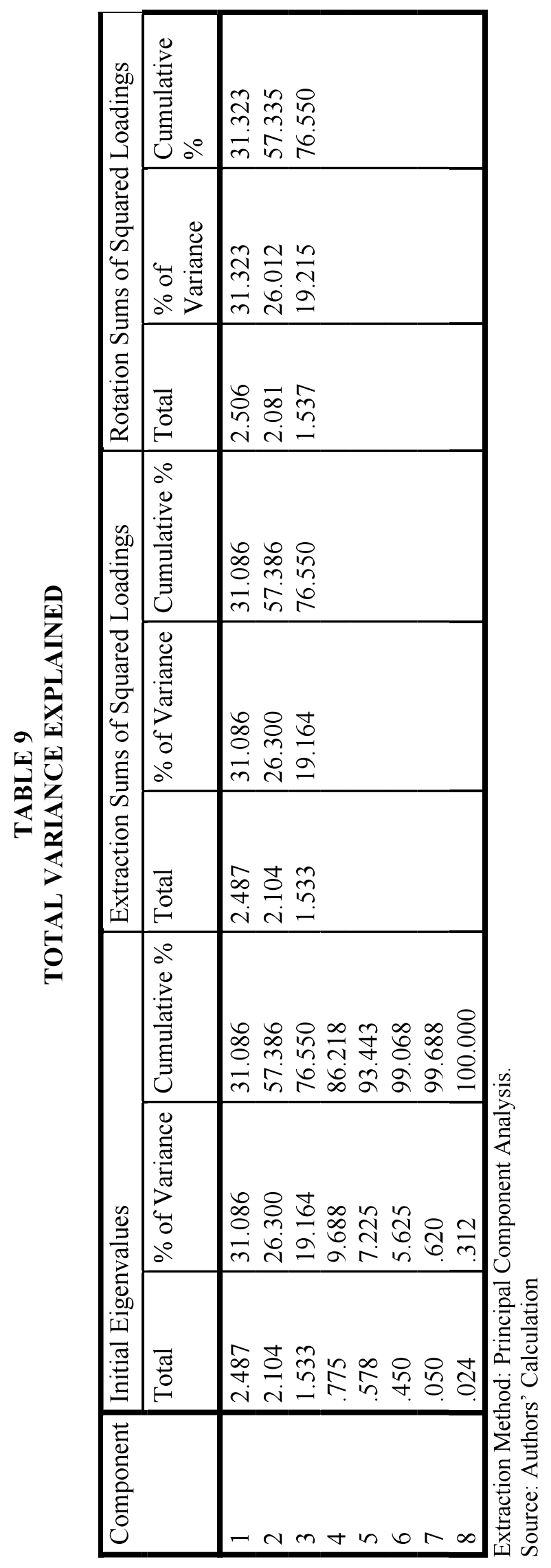


Table 9 comprises of three blocks. Block (a) gives the Eigen values and the percentage of total variance explained by each factor. Whereas Block (b) gives the Eigen values along with the percentage of total variance reported by each factor after rotation. Factors having Eigen value more than 1 would be retained and considered for further analysis. Based on this, the following three factors have been identified for further analysis and deliberation, instructor's ability to influence, motivate and inspire students, ease of learning in terms of conceptual understanding and ample opportunities for students to interact with the instructor. These three factors together are accounting for 95.30 per cent of the total variance.

These three identified factors are chosen for regression analysis with overall students' satisfaction and perceived effectiveness of online teaching as dependent variable.

\section{TABLE 10 \\ PEARSON CORRELATION MATRIX}

\begin{tabular}{|l|l|l|l|l|l|}
\hline & $\begin{array}{l}\text { Overall } \\
\text { Satisfaction and } \\
\text { perceived } \\
\text { effectiveness }\end{array}$ & $\begin{array}{l}\text { Instructor's ability to } \\
\text { influence, motivate } \\
\text { and inspire students } \\
\text { (Factor 1) }\end{array}$ & $\begin{array}{l}\text { ease of } \\
\text { learning } \\
\text { (Factor 2) }\end{array}$ & $\begin{array}{l}\text { Interaction } \\
\text { with } \\
\text { instructors } \\
\text { (Factor 3) }\end{array}$ & VIF \\
\hline $\begin{array}{l}\text { Overall Satisfaction(Y) } \\
\text { and perceived } \\
\text { effectiveness }\end{array}$ & 1.000 & & & & 3.042 \\
\hline $\begin{array}{l}\text { Instructor's ability to } \\
\text { influence, motivate and } \\
\text { inspire students }\end{array}$ & $.716^{*}$ & 1.000 & & & \\
\hline Ease of learning & $.621^{* *}$ & $.545^{* *}$ & 1.000 & & 3.712 \\
\hline $\begin{array}{l}\text { Interaction with } \\
\text { instructors }\end{array}$ & $.618^{* *}$ & $.590^{* *}$ & & 1.000 & 3.918 \\
\hline
\end{tabular}

Notes: ${ }^{*} \mathrm{p}<0.05$ (two tailed); ${ }^{* *} \mathrm{p}<0.01$ (two tailed)

Source: Authors' calculation

Table 10 shows the correlation matrix of independent and dependent variables. From the table, it can be inferred that all the three independent variables chosen have high positive correlation with dependent variables. High positive correlation is also observed between instructor's ability to influence, motivate and inspire students (Factor 1) and other two independent variables i.e., ease of learning (Factor 2) and interaction with instructors (Factor 3). The issue of multicollinearity is often encountered in multiple regression. For this the test for Variance Inflation Factor (VIF) has been conducted and its values can be seen in Table 9. As seen from the table, the VIF value for each variable is less than 10, hence the chances of multicollinearity are not high between the variables (Neter et al.,1996).

\section{TABLE 11 MODEL SUMMARY}

\begin{tabular}{|l|l|l|l|l|}
\hline Model & R & R Square & Adjusted R Square & Std. Error of the Estimate \\
\hline 1 & $.681^{\mathrm{a}}$ & .614 & .575 & .295028 \\
\hline
\end{tabular}

a: Predictors: constant, Factor1, Factor 2, Factor 3.

Source: Authors' calculations

As seen from the table 11, independent variables of the study are able to explain 61.4 per cent variability in the dependent variable i.e., overall satisfaction and perceived effectiveness. 
TABLE 12

ANOVA ${ }^{\mathrm{a}}$

\begin{tabular}{|l|l|l|l|l|}
\hline Model & Sum of Squares & Mean Square & F & Sig. \\
\hline Regression & 15.208 & 5.069 & 38.358 & $.000^{\mathrm{b}}$ \\
\hline Residual & 29.120 & 1.038 & & \\
\hline Total & 44.328 & & & \\
\hline
\end{tabular}

a: Independent Variable: Overall satisfaction

b: Predictors: constant, Factor1, Factor 2, Factor 3

Source: Authors' calculations

Table 12 shows the overall model fit. The model is fit at 95 per cent confidence level with probability value almost zero and higher tabular $\mathrm{F}$ value.

TABLE 13

COEFFICIENTS ${ }^{a}$

\begin{tabular}{|c|c|c|c|c|c|c|c|}
\hline \multirow{2}{*}{ Model 1} & \multicolumn{2}{|c|}{$\begin{array}{l}\text { Unstandardized } \\
\text { Coefficients }\end{array}$} & \multirow{2}{*}{$\begin{array}{l}\text { Standardized } \\
\text { Coefficients } \\
\text { Beta }\end{array}$} & \multirow[b]{2}{*}{$\mathbf{t}$} & \multirow[b]{2}{*}{ Sig. } & \multicolumn{2}{|c|}{$\begin{array}{l}\text { Collinearity } \\
\text { Statistics }\end{array}$} \\
\hline & B & Std. Error & & & & Tolerance & VIF \\
\hline $\mathrm{Y}$ & .735 & .041 & & 17.953 & .000 & & \\
\hline Factor 1 & .413 & .005 & .694 & 5.241 & .000 & .882 & 3.042 \\
\hline Factor 2 & .123 & .001 & .274 & 4.709 & .000 & .356 & 3.712 \\
\hline Factor 3 & .072 & .021 & .137 & 3.499 & .001 & .787 & 3.918 \\
\hline
\end{tabular}

a: Independent Variable: Overall satisfaction and perceived effectiveness

Source: Authors' calculations

The signs of beta coefficients define, if the variables under the study are positively or negatively related. As per values in Table 5, all the three factors are positively related with the overall satisfaction of students and their perceptions of effectiveness about online teaching. As it can be seen from the table 5, all the three variables are statistically significant at the 95 per cent confidence level.

\section{CONCLUSION}

This study provides a rich overview of students' reactions and perceptions when they were forced to make a transition to online mode of learning. This study also tried to explore and identify the factors constituting and affecting the students' perceptions regarding online teaching-learning.

First objective of this study was to understand the student's perceptions, regarding various online teaching options. Of the various common options, used by the instructors during online teaching, this study indicates that sharing of prepared power point presentations and sharing of notes are most preferred by students. Study also attempts to identify various factors having a bearing on student's perceptions regarding effectiveness of online teaching. After extensive literature review, seven factors were identified which can have a significant bearing on students' perceptions. Of these, factor analysis concluded that three factors i.e., instructor's ability to influence, motivate and inspire students, ease of learning in terms of conceptual understanding and opportunities for students to interact with the instructors are to be considered for further analysis. All these three factors are significant in influencing the perception of students regarding online learning and their satisfaction. Students perceive technical support as the biggest challenge coming in the way of online teaching followed by lack of awareness among themselves with the changed learning style in case of online teaching. Study also reveals that more than 60 per cent students were satisfied with the 
way and manner in which online teaching has been conducted. Overall a positive perception of students has been observed towards online learning experience as seen in several other studies (Scagnoli et.al, 2019; Spiceland and Hawkins, 2002). Thus, it can be concluded that students are found to be satisfied with the online mode of teaching provided by various management institutions. Positive approach and acceptance of students for this methodology in the present scenario indicates that a blended approach can be worked out. For better acceptance of online teaching- learning, following framework is suggested by the authors.

\section{FIGURE 1 \\ SUGGESTED FRAMEWORK}

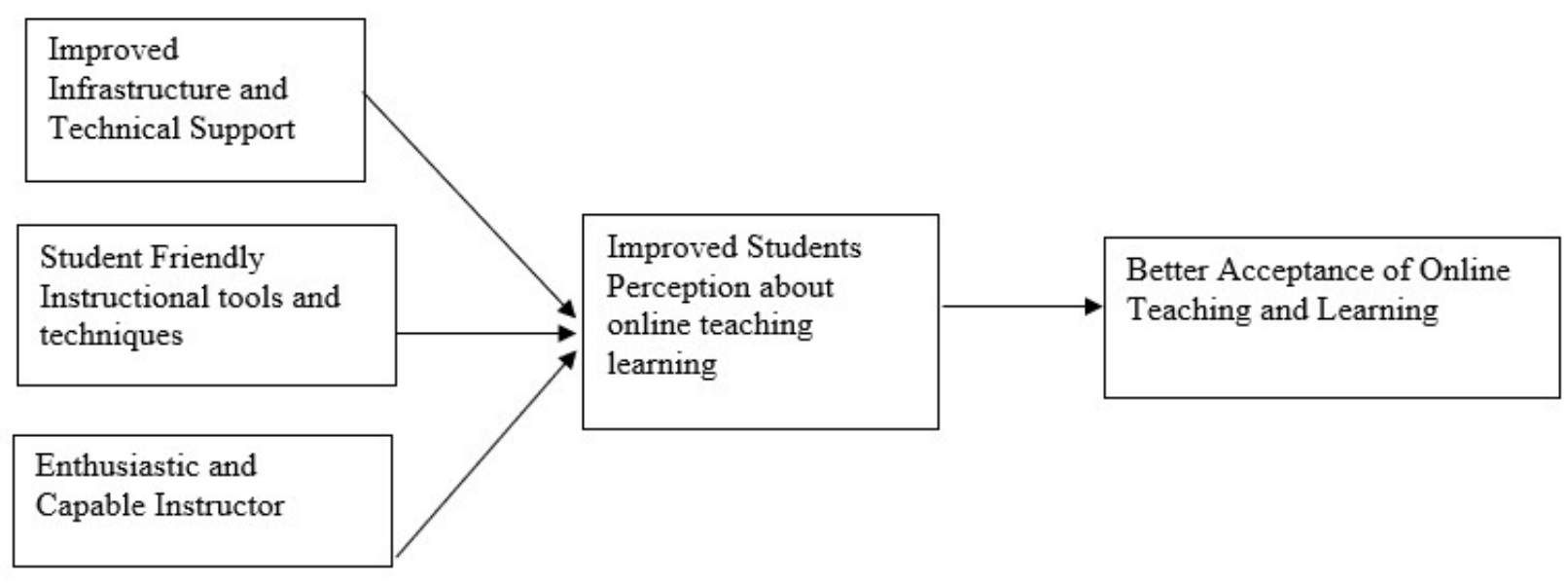

One silver lining of this compulsory online learning can be that it exposed 62 per cent of students to their first ever online learning experience. These 62 per cent of students will be more receptive for online teaching as previous researches have indicated that students with prior experience are more receptive (Cigdem and Yildirim, 2014; Fogerson, 2005). Secondly with the rapid usage of technology in industries, it will also help them in becoming industry ready.

Results from this study can aid in development of rich blended approach in University post graduate management programmes. Latest UGC guidelines (2020) has also recommended 75 per cent traditional and 25 per cent online teaching module.

This sudden shift in teaching learning spectrum is challenging both for students and instructors alike. A Way ahead is to build confidence amongst students and also to keep them in confidence. A student centric scientific system of assessment needs to be developed. Concept of rubrics may be given due importance as in rubrics achievement criterion is clearly specified.

This study indicates the need of identification and implementation of the appropriate and effective strategies which can enable proper student -instructor communication in online teaching.

\section{LIMITATIONS AND FUTURE SCOPE}

In this study no sampling technique has been used. The chosen respondents were second year students from two-year programme who voluntarily participated and responded to questionnaire.

This study has focused only on few of the possible relationships about perception of the online teaching. Students perception is a multidimensional concept and hence several other possible relationships can be explored in future studies.

This study is based on perceptions of management students from the selected HEIs in the state of Maharashtra. Future study can be devised appropriately to cover entire Maharashtra as well as in the other states of India. Future studies can also focus on the link between learners' perception and outcome in an online environment. This study is certainly the first step in this process of developing blended learning 
approach for university affiliated tier-II B-schools in India. Based on this understanding of student's perceptions of online learning, inter relationship between various aspects of online and face to face learning can be explored. Future studies may also focus on detailed analysis of various online teaching methods and tools for increasing the learning quality.

\section{REFERENCES}

Agarwal, S., \& Kaushik, J.S. (2020). Student's perception of online learning during COVID pandemic. The Indian Journal of Pediatrics, 87, 554-554. DOI: 10.1007/s12098-020-03327-7

Annamdevula., S., \& Bellamkonda, R.S. (2016). Effect of student perceived service quality on student satisfaction, loyalty and motivation in Indian universities: development of HiEduQual. Journal of Modelling in Management,1I(2), 488-517. DOI: 10.1108/JM2-01-2014-0010

Arbaugh, J., \& Benbunan-Fich, R. (2007). The importance of participant interaction in online environments. Decision Support Systems, 43(3), 853-865. DOI: 10.1016/j.dss.2006.12.013

Artino, A.R. (2008). Motivational beliefs and perceptions of instructional quality: Predicting satisfaction with online training. Journal of computer assisted learning, 24(3), 260-270. DOI:10.1111/j.13652729.2007.00258.x

Azliza, Y., Kadir, A.Z.A., Zainudin, O., \& Zurairah, A. (2012). Students awareness toward e-learning in education, Procedia - Social and Behavioral Sciences, 67, 93-101. DOI: $10.1016 /$ j.sbspro.2012.11.310

Babchuk, W.A. (2017). Book review: Qualitative research: a guide to design and implementation (4th ed.). In S. B. Merriam \& E. J. Tisdell. Adult Education Quarterly, 67(1), 71-73.

DOI: $10.1177 / 0741713616671930$

Bao, W. (2020). COVID -19 and online teaching in higher education: A case study of Peking University. Human Behavior and Emerging Technologies, 2(2), 113-115. DOI: 10.1002/hbe2.191

Bauk, S., Kopp, M., \& Avramović, Z. (2013). A case study on introducing e-learning into seafarers' education, JITA - Journal of Information Technology and Applications, 3(1), 34-43. DOI: $10.7251 / \mathrm{JIT} 1301034 \mathrm{~B}$

Blizak, D., Blizak, S., Bouchenak, O., \&Yahiaoui, K. (2020). Students' Perceptions Regarding the Abrupt Transition to Online Learning During the COVID-19 Pandemic: Case of Faculty of Chemistry and Hydrocarbons at the University of Boumerdes-Algeria. Journal of Chemical Education, 97(9), 2466-2471. DOI: 10.1021/acs.jchemed.0c00668

Castle, S.R., \& McGuire, C. (2010). An analysis of student self-assessment of online, blended, and face to- face learning environments: implications for sustainable education delivery. International Education Studies, 3(3), 36-40. DOI: 10.5539/ies.v3n3p36

Cigdem, H., \& Yildirim, O.G. (2014). Effects of students' characteristics on online learning readiness: A vocational college example. Turkish Online Journal of Distance Education, 15(3), 80-93. DOI: $10.17718 /$ tojde.69439

Choy, S., McNickle, C., \& Clayton, B. (2002). Learner expectations and experiences: An examination of student views of support in online learning. National Center for Vocational Education and Research. Retrieved August 8, 2020, from http://www.NCVER.edu/au/research/proj/rr 0F01.pdf

Cooper, L. (2000). On-line courses tips for making them work. Technological Horizons in Education Journal, 27(8), 87-92.

Creswell, J.W., \& Poth, C. N. (2016). Qualitative inquiry \& research design: Choosing among five approaches (4th ed.). SAGE Publications.

Cronbach, L.J. (1951). Coefficient alpha and the internal structure of tests. Psychometrika, 16, 297-334.

Cunningham, T., McDonnell, C., McIntyre, B., \& McKenna, T. (2009). A reflection on teachers' experience as e-learners. In Applied E-learning and E-teaching in Higher Education (pp. 56-84). IGI Global DOI: 10.4018/9781599048147.ch004 
Davis, F.D., Bagozzi, R.P., \& Warsaw, P.R. (1989). User acceptance of computer technology: A comparison of two theoretical models. Management Science, 35, 982-1003.

DOI: $10.1287 / \mathrm{mnsc} .35 .8 .982$

Demuyakor, J. (2020). Coronavirus (COVID-19) and online learning in higher institutions of education: A survey of the perceptions of Ghanaian international students in China. Online Journal of Communication and Media Technologies, 10(3), e202018. DOI: 10.29333/ojcmt/8286

Deng, L., \& Tavares, N. (2013). From moodle to Facebook: Exploring students' motivation and experiences in online communities. Computers \& Education, 68, 167-176.

DOI: 10.1016/j.compedu.2013.04.028

Denny, P. (2013, April). The effect of virtual achievements on student engagement. In Proceedings of the SIGCHI conference on human factors in computing systems (pp. 763-772). DOI: $10.1145 / 2470654.2470763$

Dirr, P.J. (1999). Distance and Virtual Learning in the United States. In THE DEVELOPMENT OF VIRTUAL EDUCATION: A GLOBAL PERSPECTIVE. Edited by G.M. Farrell, Vancouver, BC: Commonwealth of Learning, pp. 23-48.

Dogbey, J., Kumi-Yeboah, A., \& Dogbey, J. (2017). Dialogue Pedagogical Strategies Perceived to Enhance Online Interaction: Instructors' Perspective. International Journal of Online Pedagogy and Course Design (IJOPCD), 7(3), 70-85. DOI: 10.4018/ijopcd.2017070105

Donitsa-Schmidt, S., \& Topaz, B. (2018). Massive open online courses as a knowledge base for teachers. Journal of Education for Teaching, 44(5), 608-620. DOI: 10.1080/02607476.2018.1516350

Driver, M. (2002). Exploring student perceptions of group interaction and class satisfaction in the webenhanced classroom. Internet \& Higher Education, 5(1), 35-46. DOI: 10.1016/S10967516(01)00076-8

Dunbar, R.I.M., \& Sutcliffe, A.G. (2013). Social complexity and intelligence. In Vonk, J., Shackelford, T. K. (Eds.), The Oxford handbook of comparative evolutionary psychology (pp. 102-117). New York, NY: Oxford University Press.

Feeley, M., \& Parris, J. (2012). An Assessment of the PeerWise Student-Contributed Question System's Impact on Learning Outcomes: Evidence from a Large Enrollment Political Science Course. Available at SSRN 2144375. DOI: 10.2139/ssrn.2144375

Filius, R.M., Kleijn, R.A.M., Uijl, S.G., Prins, F J., Rijen, H.V.M., \& Grobbee, D.E. (2019). Audio peer feedback to promote deep learning in online education. Journal of Computer Assisted Learning, 35(5), 607-619. DOI: $10.1111 /$ jcal.12363

Fogerson, D.L. (2005). Readiness factors contributing to participant satisfaction in online higher education courses.

Garcia, C., \& Badia, A. (2017). Information problem-solving skills in small virtual groups and learning outcomes: IPS skills and learning outcomes. Journal of Computer Assisted Learning, 33(4), 382392. DOI: $10.1111 /$ jcal.12187

Gaytan, J., \& McEwen, B.C. (2007). Effective online instructional and assessment strategies. The American Journal of Distance Education, 21(3), 117-132. DOI: 10.1080/08923640701341653

Gregory, V.L. (2003). Student perceptions of the effectiveness of Web-based distance education. New Library World, 104(10), 426- 431. DOI: 10.1108/03074800310504366

Hair, J.F., Anderson, R.E., Tatham, R.L., \& Black, W.C. (1995). Multivariate Data analysis (4th ed.). Prentice-Hall, Englewood Cliffs, NJ.

Harris, G. E., \& Kelley, G. (2004-2006). The development and implementation of online undergraduate and graduate systems security courses: Lessons learned. Information Technology, Learning, and Performance Journal, 22(3), 65-82.

Hativa, N., Barak, R., \& Simhi, E. (2001). Exemplary university teachers: Knowledge and beliefs regarding effective teaching dimensions and strategies. Journal of Higher Education, 72(6), 699729. DOI: $10.2307 / 2672900$

Howland, J.L., \& Moore, J.L. (2002). Student perceptions as distance learners in Internet-based courses. Distance Education, 23(2), 183-196. 
Islam, A.N. (2012). Understanding e-learning system usage outcomes in hybrid courses. In 2012 45th Hawaii International Conference on System Sciences (pp. 118-127). IEEE. doi:10.1109/HICSS.2012.613

Jia, Y., Way, N., Ling, G., Yoshikawa, H., Chen, X., Hughes, D., ... Lu, Z. (2009). The influence of student perceptions of school climate on socioemotional and academic adjustment: A comparison of Chinese and American adolescents. Child development, 80(5), 1514-1530.

DOI: $10.1111 / \mathrm{j} .1467-8624.2009 .01348 . x$

Kaiser, H.F. (1974). An index of factorial simplicity. Psychometrika, 39(1), 31-36.

Kashefi, H., Ismail, Z., \& Yusof, Y.M. (2012). Supporting engineering students' thinking and creative problem solving through blended learning, Procedia - Social and behavioral Sciences, 56, 117125. DOI: $10.1016 /$ j.sbspro.2012.09.638

Keller, C., \& Cernerud, L. (2002). Students' perception of e-learning in university education. Journal of Educational Media, 27, 1-2, 55-65. DOI: 10.1080/1358165020270105

Köse, U. (2010), A blended learning model supported with Web 2.0 technologies, Procedia - Social and Behavioral Sciences, 2, 2794-2802. DOI: 10.1016/j.sbspro.2010.03.417

Lack, K. A. (2013). Current status of research on online learning in postsecondary education. Ithaka S+ $R, 3$.

Laine, L. (2003). Is e-learning effective for IT training? $T+D, 57(6)$, 55-60.

Linjawi, A.I., \& Alfadda, L.S. (2018). Students' perception, attitudes, and readiness toward online learning in dental education in Saudi Arabia: a cohort study. Advances in Medical Education and Practice, 9, 855. DOI: 10.2147/AMEP.S175395

Lewin, L.O., Singh, M., Bateman, B.L., \& Glover, P.B. (2009). Improving education in primary care: development of an online curriculum using the blended learning model. BMC Medical Education, 9(1), 33. DOI: 10.1186/1472-6920-9-33

McGreal, R., \& Elliott, M (2004). Technologies of online learning (e-learning) [Electronic version]. In T. Anderson \& F. Elloumi (Eds), Theory and Practice of Online Learning (pp. 115-135). Athabasca, Canada: Athabasca University.

Nambiar, D. (2020). The impact of online learning during COVID-19: students' and teachers' perspective. The International Journal of Indian Psychology, 8(2), 783-793. DOI: $10.25215 / 0802.094$

Neter, J., Kutner, M.H., Nachtsheim, C.J., \& Wasserman, W. (1996). Applied linear statistical models Nguyen, T. (2015). The effectiveness of online learning: Beyond no significant difference and future horizons. MERLOT Journal of Online Learning and Teaching, 11(2), 309-319.

Ozkan, S., \& Koseler, R. (2009). Multi-dimensional students' evaluation of e-learning systems in the higher educational context: An empirical investigation. Computers \& Education, 53, 1285-1296. DOI: 10.1109/FIE.2009.5350590

Perez-Marin D., Santacruz, L., \& Gomez, M. (2012). A proposal for a blended learning methodology and how to apply it with university students. Procedia - Social and Behavioral Sciences, 46, 54585462. DOI: $10.1016 /$ j.sbspro.2012.06.457

Rhema, A., \& Miliszewska, I. (2014). Analysis of student attitudes towards e-learning: The case of engineering students in Libya. Issues in informing science and information Technology, 11, 169190. DOI: $10.28945 / 1987$

Sahin, I., \& Shelley, M. (2008). Considering students' perceptions: The distance education student satisfaction model. Educational Technology \& Society, 11(3),216-223.

Sandercock, G., \& Shaw, G. (2000). Learners' performance and evaluation of attitude towards web course tools in the delivery of an applied sports science module. Journal of Asynchronous Learning, $3(2), 1-10$

Scagnoli, N.I., Choo, J., \& Tian, J. (2019). Students' insights on the use of video lectures in online classes. British Journal of Educational Technology, 50(1), 399-414. DOI: 10.1111/bjet. 12572

Schmitt, N. (1996). Uses and abuses of coefficient alpha. Psychological assessment, 8(4), 350. 
Shea, P., Fredericksen, E., Pickett, A., Pelz, W., \& Swan, K. (2001). Measures of learning effectiveness in the SUNY Learning Network.

Sonner, B. S. (1999). Success in the capstone business course -- assessing the effectiveness of distance learning. Journal of Education for Business, 74(4), 243-247. DOI: 10.1080/08832329909601692

Spiceland, J.D., \& Hawkins, P.C. (2002). The impact on learning of an asynchronous active learning course format. Journal of Asynchronous Learning Networks, 6(1), 68-75. DOI: $10.24059 /$ olj.v6i1.1873

Swan, K. (2001). Virtual interaction: Design factors affecting student satisfaction and perceived learning in asynchronous online courses. Distance education, 22(2), 306-331. DOI: $10.1080 / 0158791010220208$

Tratnik, A., Urh, M., \& Jereb, E. (2019). Student satisfaction with an online and a face-to-face Business English course in a higher education context. Innovations in Education and Teaching International, 56(1), 36-45. DOI: 10.1080/14703297.2017.1374875

Trigwell, K. (2001). Judging university teaching. International Journal for Academic Development, 6(1), 65-73. DOI: $10.1080 / 13601440110033698$

Tung, F.C., \& Chang, S.C. (2008). Nursing students' behavioral intention to use online courses: A questionnaire survey. International journal of nursing studies, 45(9), 1299-1309. DOI: 10.1016/j.ijnurstu.2007.09.011

Verma, A., Verma, S., Garg, P., \& Godara, R. (2020). Online teaching during COVID-19: perception of medical undergraduate students. Indian Journal of Surgery, 82(3), 299-300.

DOI: $10.1007 / \mathrm{s} 12262-020-02487-2$

Vonderwell, S. (2003). An examination of asynchronous communication experiencesand perspectives of students in an online course: A case study. Internet and Higher Education, 6(1), 77-90. DOI: 10.1016/S1096-7516(02)00164-1

Waits, T. (2003). Distance education at degree-granting postsecondary institutions: 2000-2001. National Center for Education Statistics.

Wang, H., Pi, Z., \& Hu, W. (2019). The instructor's gaze guidance in video lectures improves learning. Journal of Computer Assisted Learning, 35(1), 42-50. https://doi.org/10.1111/jcal.12309

Wilkes, R.B., Simon, J.C., \& Brooks, L.D. (2006). A Comparison of Faculty and Undergraduate Students' Perceptions of Online Courses and Degree Programs. Journal of Information Systems Education, 17(2).

Woods R.H. Jr. (2002). How much communication is enough in online courses? -exploring the relationship between frequency of instructor-initiated personal email and learners' perceptions of and participation in online learning. International Journal of Instructional Media, 29(4), 377.

Zhang, P., \& Bhattacharyya, S. (2008). Students' views of a learning management system: A longitudinal qualitative study. Communications of the Association for Information Systems, 23(1), 20.

DOI: $10.17705 / 1$ CAIS.02320 